\title{
The association between dietary isoflavones intake and gastric cancer risk: a meta-analysis of epidemiological studies
}

\author{
Jie You', Yafei Sun ${ }^{\dagger}$, Yacong Bo, Yiwei Zhu, Dandan Duan, Han Cui and Quanjun Lu*
}

\begin{abstract}
Background: Isoflavones, a class of phytoestrogenic compounds, are abundant in soybeans. A number of epidemiological studies have investigated the association between dietary isoflavones intake and the risk of gastric cancer. However, the results are inconclusive. Therefore, the meta-analysis was conducted to evaluate the effect of dietary isoflavones intake on the risk of gastric cancer.

Methods: Relevant studies from May 1992 to May 2017 were identified through searching PubMed and Web of Science. Additional articles were identified from the reference lists of relevant review articles. Pooled risk ratios (RRs) or odds ratios (ORs) and 95\% confidence intervals (Cls) were calculated using a fixed-effects model. Funnel plot and Egger's test were used to evaluate publication bias.

Results: Seven articles reporting 12 studies were included in the current meta-analysis. We found no significant association between dietary isoflavones intake and gastric cancer risk with the highest versus the lowest categories of dietary isoflavones intake $\left(\mathrm{OR}=0.97,95 \% \mathrm{Cl}=0.87-1.09, I^{2}=27.5 \%\right)$. Subgroup analyses generally yield similar results.
\end{abstract}

Conclusions: Higher dietary isoflavones intake is not associated with a decline in the risk of gastric cancer.

Keywords: Gastric cancer, Dietary isoflavones intake, Meta-analysis

\section{Background}

Gastric cancer, including gastric adeno-carcinoma and gastric cardia adeno-carcinoma, was the third leading cause of death in the world which accounting for 8 . $8 \%$ of the total cancer death, according to GLOBOCAN 2012 [1]. It is estimated that there were 951,600 new gastric cancer cases and 723,100 deaths occurred in 2012.

Epidemiological studies have suggested that high fruits and vegetables intake are inversely associated with the risk of gastric cancer [2, 3]. Isoflavones, the second metabolites during the growth of soybeans, are a group of bioactive polyphenols, which have a variety of physiological functions to human body [4]. Several epidemiological studies have investigated the

\footnotetext{
* Correspondence: lajnutr@zzu.edu.cn

${ }^{\dagger}$ Equal contributors

Department of Nutrition and Food Hygiene, College of Public Health

Zhengzhou University, Zhengzhou 450001, Henan, China
}

relationship between dietary isoflavones intake and the risk of gastric cancer, but the results are conflicting. Therefore, we conducted the current metaanalysis to further identify the effect of dietary isoflavones intake on the risk of gastric cancer.

\section{Methods \\ Data sources and search strategy}

We searched all relevant literature from May 1992 to May 2017 using electronic databases PubMed and Web of Science, with the search terms: ("isoflavones" or "soy isoflavones" or "phytoestrogen" or "genistein" or "daidzein") and ("gastric cancer" or "gastric tumor" or "stomach cancer" or "stomach tumor"). Additional articles were identified from the reference lists of relevant review articles.

(c) The Author(s). 2018 Open Access This article is distributed under the terms of the Creative Commons Attribution 4.0 International License (http://creativecommons.org/licenses/by/4.0/), which permits unrestricted use, distribution, and reproduction in any medium, provided you give appropriate credit to the original author(s) and the source, provide a link to the Creative Commons license, and indicate if changes were made. The Creative Commons Public Domain Dedication waiver (http://creativecommons.org/publicdomain/zero/1.0/) applies to the data made available in this article, unless otherwise stated. 


\section{Inclusion criteria and exclusion criterion}

Studies were selected for analysis according to the following inclusion criteria: (1) investigated the relationship of dietary isoflavones intake and gastric cancer risk; (2) the studies were either cohort or case-control studies; (3) articles reported the estimated RR/OR with their 95\% $\mathrm{CI}$ or the indexes could be calculated. (4) articles were published in English literature. If two or more studies shared same data sets, the one with the largest sample size or the longest follow-up period was selected in the meta-analysis.

Studies were excluded if they are: (1) cell studies and animal studies; (2) reviews articles, letters to the editor and case reports; (3) isoflavones were measured with the levels in blood/urinary; (4) the RR/OR with 95\% CI could not be estimated from the data in the articles.

\section{Data extraction}

Two reviewers (Jie You and Yafei Sun) extracted the following information independently: (1) the last name of first author; (2) year publication; (3) country; (4) study design; (5) geographic area; (6) source of control; (7) participants' characteristics (including the range of age, gender, the total number of participants, the number of cases and controls); (8) isoflavones assessment method; (9) the RRs/ORs and their 95\% CIs indicating the highest versus the lowest categories of dietary isoflavones intake; (10) adjustment for covariates. Any discrepancies were definitely resolved by a third senior professor (Quanjun Lu). The quality of the selected papers was assessed by use of the Newcastle-Ottawa scale before pooled into the analysis [5]. The scores of $0-3,4-6$, and 7-9 were considered as low, moderate, and high quality, respectively. Finally, data extraction from included studies was shown in Additional file 1.

\section{Statistical analysis}

The association between the dietary isoflavones intake and the risk of gastric cancer was calculated with the pooled ORs together with their 95\% CIs. If $P<0.05$ and/or $I^{2}>50 \%$, the random-effects model was conducted. Otherwise, a fixed-effects model was used. Chi-square test and the $I^{2}$ test were used to quantify the heterogeneity of the studies. Subgroup analyses by study design (the type of case-control or cohort study), gender, geographic area, source of control (based on population or hospital), sample size, dietary assessment, adjustments (family history and dietary energy intake) were also performed to find potential confounder/ modifier.

Egger's test and Funnel plots were conducted to assess the potential publication bias, and a value of $P<0.05$ was considered as a significant difference. All statistical analyses were conducted with the software STATA version 12.0 (Stata Corporation, College Station, TX, USA).

\section{Results}

\section{Characteristics of the included studies}

The process of our articles selecting is presented in Fig. 1, a total of 204 potential relevant articles were obtained from PubMed and Web of Science. Fourty eight articles were identified by reviewing the titles and abstracts. Among these remaining 48 articles, eight articles were reviews, 28 articles reported isoflavones supplements, and two articles did not report OR/RR (or 95\% CI). Finally, seven articles reporting 12 studies were included in our study, three articles with 6 cohort studies [6-8] and four

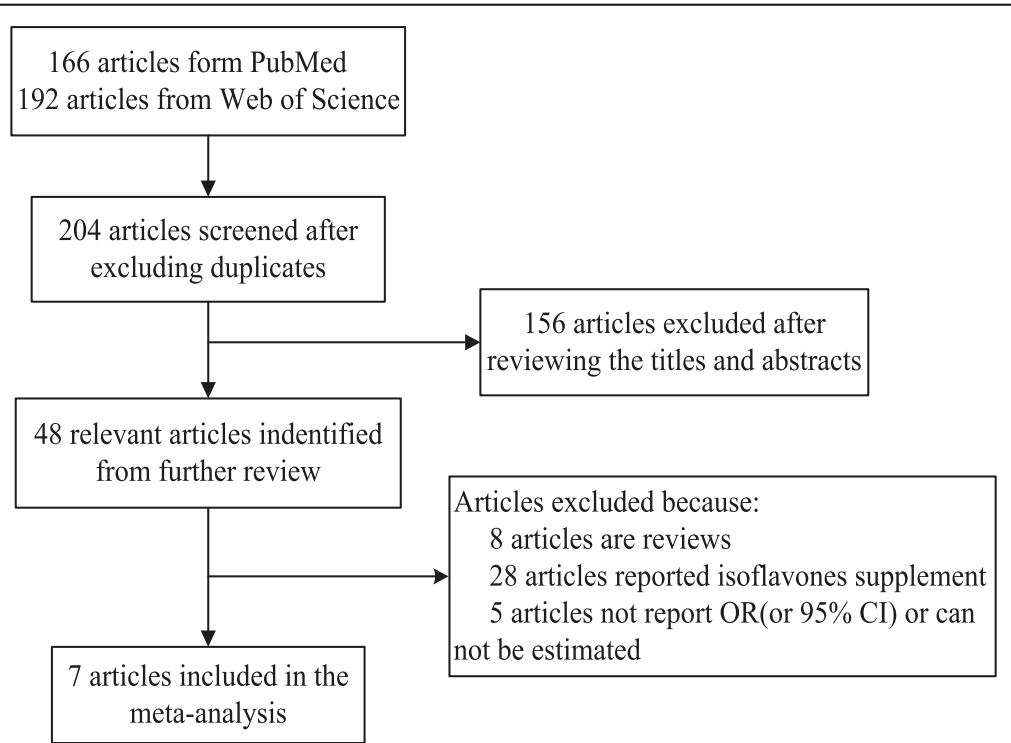

Fig. 1 A flow diagram for selection studies and exclusion reason for the meta-analysis 
Table 1 Characteristics of studies on dietary isoflavones intake and risk of gastric cancer

\begin{tabular}{|c|c|c|c|c|c|c|c|c|c|}
\hline $\begin{array}{l}\text { First author } \\
\text { (year) } \\
\text { County [no.] }\end{array}$ & $\begin{array}{l}\text { Study } \\
\text { design }\end{array}$ & $\begin{array}{l}\text { Source of } \\
\text { control }\end{array}$ & Age (y) & $\begin{array}{l}\text { Dietary } \\
\text { assessment }\end{array}$ & $\begin{array}{l}\text { Participants } \\
\text { (cases) }\end{array}$ & $\begin{array}{l}\text { Intake } \\
\text { comparison, } \\
\text { high vs. Low } \\
\text { (mg/d) }\end{array}$ & $\begin{array}{l}\text { OR }(95 \% \mathrm{Cl}) \text { for } \\
\text { highest vs. lowest } \\
\text { category }\end{array}$ & $\begin{array}{l}\text { NOS } \\
\text { Score }\end{array}$ & $\begin{array}{l}\text { Adjustment for } \\
\text { covariates }\end{array}$ \\
\hline $\begin{array}{l}\text { Hara (2012) } \\
\text { Japan [6] }\end{array}$ & Cohort & Population & $45-74$ & $\begin{array}{l}\text { Validated } \\
\text { FFQ }\end{array}$ & $\begin{array}{l}84,881 \\
(1249)\end{array}$ & $\begin{array}{l}\text { M: } 42.3 \text { vs. } 9.2^{\mathrm{a}} \\
\text { F: } 41.8 \text { vs. } 9.4^{\mathrm{a}}\end{array}$ & $\begin{array}{l}\text { M: } 1(0.81-1.24) \\
F: 1.07(0.77-1.5)\end{array}$ & 9 & $\begin{array}{l}\text { Age, public } \\
\text { health center } \\
\text { area, BMl, } \\
\text { smoking, family } \\
\text { history, ethanol, } \\
\text { vegetable and } \\
\text { fruit intake, fish } \\
\text { intake, salt } \\
\text { intake, and total } \\
\text { energy intake, } \\
\text { menopausal } \\
\text { status }\end{array}$ \\
\hline $\begin{array}{l}\text { Wada (2015) } \\
\text { Japan [7] }\end{array}$ & Cohort & Population & $>35$ & $\begin{array}{l}\text { 169-item } \\
\text { FFQ }\end{array}$ & $\begin{array}{l}30,792 \\
(678)\end{array}$ & $\begin{array}{l}\text { M: } 75.5 \text { vs. } 17.6^{\mathrm{a}} \\
\text { F: } 72.6 \text { vs. } 20.1^{\mathrm{a}}\end{array}$ & $\begin{array}{l}\text { M: } 0.81(0.60-1.09) \\
\text { F: } 0.60(0.37-0.98)\end{array}$ & 9 & $\begin{array}{l}\text { Age, BMl, } \\
\text { physical activity, } \\
\text { smoking status, } \\
\text { alcohol intake, } \\
\text { salt intake, } \\
\text { education, } \\
\text { menopausal } \\
\text { status }\end{array}$ \\
\hline $\begin{array}{l}\text { Rossi (2010) } \\
\text { Italy [11] }\end{array}$ & Case-control & Hospital & $22-80$ & $\begin{array}{l}\text { Validated } \\
\text { FFQ }\end{array}$ & $\begin{array}{l}777 \\
(230)\end{array}$ & $>34.3$ vs. $<15.0$ & $0.88(0.53-1.46)$ & 8 & $\begin{array}{l}\text { Sex, age, } \\
\text { education, } \\
\text { calendar year of } \\
\text { interview, BMl, } \\
\text { smoking intake, } \\
\text { total energy } \\
\text { intake }\end{array}$ \\
\hline $\begin{array}{l}\text { Lagiou (2004) } \\
\text { Boston [9] }\end{array}$ & Case-control & Hospital & NR & $\begin{array}{l}\text { Validated } \\
\text { FFQ }\end{array}$ & $\begin{array}{l}210 \\
(110)\end{array}$ & 2.85 vs. $0.01^{a}$ & $1.16(0.73-1.84)$ & 7.5 & $\begin{array}{l}\text { Age, sex, place } \\
\text { of birth, BMI, } \\
\text { height, } \\
\text { education, } \\
\text { smoking and } \\
\text { alcohol } \\
\text { consumption, } \\
\text { total energy } \\
\text { intake, fruit and } \\
\text { vegetable intake }\end{array}$ \\
\hline $\begin{array}{l}\text { Petrick (2015) } \\
\text { America [10] }\end{array}$ & Case-control & Population & $30-79$ & $\begin{array}{l}\text { 104-item } \\
\text { FFQ }\end{array}$ & $\begin{array}{l}1913 \\
(589)\end{array}$ & $\begin{array}{l}\text { GCA:0.6 vs. } 0.27^{\mathrm{a}} \\
\text { OG:0.6 vs. } 0.27^{\mathrm{a}}\end{array}$ & $\begin{array}{l}\text { GCA:1.56 } \\
(0.93-2.6) \\
\text { OG:1.5 (0.96-2.37) }\end{array}$ & 9 & $\begin{array}{l}\text { Proxy status, } \\
\text { income, } \\
\text { education, BMI, } \\
\text { cigarette and } \\
\text { alcohol } \\
\text { consumption }\end{array}$ \\
\hline $\begin{array}{l}\text { Woo (2014) } \\
\text { Korea [12] }\end{array}$ & Case-control & Hospital & $35-75$ & $\begin{array}{l}\text { 103-item } \\
\text { FFQ }\end{array}$ & $\begin{array}{l}334 \\
(334)\end{array}$ & 43.7 vs. $11.4^{\mathrm{a}}$ & $\begin{array}{l}\text { M:0.98 (0.56-1.73) } \\
\text { F:0.67 (0.31-1.47) }\end{array}$ & 6 & $\begin{array}{l}\text { Age, BMI, total } \\
\text { energy intake, } \\
\text { H.pyloristatus, } \\
\text { occupation, } \\
\text { smoking and } \\
\text { alcohol intake, } \\
\text { meat intake, } \\
\text { fruits and } \\
\text { vegetables } \\
\text { intake, physical } \\
\text { activity }\end{array}$ \\
\hline $\begin{array}{l}\text { Zamora-Ros } \\
\text { (2012) Europe } \\
{[8]}\end{array}$ & Cohort & Population & $35-70$ & $\begin{array}{l}\text { Validated } \\
\text { FFQ }\end{array}$ & $\begin{array}{l}477,312 \\
(683)\end{array}$ & $>1.1$ vs. $<0.3$ & $\begin{array}{l}\text { M: } 0.77(0.5-1.18) \\
F: 1.05(0.61-1.82)\end{array}$ & 9 & $\begin{array}{l}\text { Age, BMI, } \\
\text { education, } \\
\text { smoking, } \\
\text { alcohol, physical } \\
\text { activity, energy } \\
\text { intake, fruit and } \\
\text { vegetables } \\
\text { intake, red and } \\
\text { processed meat } \\
\text { intake }\end{array}$ \\
\hline
\end{tabular}


articles with six case-control studies [9-12], altogether with a total of 596,553 participants among the 12 studies. Hara et al. [6] found an inverse association between isoflavone intake and gastric cancer among exogenous female hormone users. Moreover, the inverse association was also detected in the Takayama study [7]. The remaining ten studies did not find significant effect of dietary isoflavone intake on gastric cancer [6-12]. The main characteristics of the included studies are presented in Table 1.

\section{Dietary isoflavones intake and risk of gastric cancer}

The pooled ORs with 95\%CI (highest versus lowest categories of dietary isoflavones intake) were calculated to assess the association between dietary isoflavones intake and the risk of gastric cancer. Compared to the lowest dietary isoflavones intake, the highest level was not significantly associated with the risk of gastric cancer (overall $\mathrm{OR}=0.97,95 \% \mathrm{CI}=0.87-1.09, I^{2}=27.5 \%$ ) (Fig. 2). Subgroup analysis also yield the similar results (Table 2).

\section{Heterogeneity analysis}

The heterogeneity in the meta-analysis was relatively low $\left(I^{2}=27.5 \%\right)$. Meta-regression suggested that study design (case-control or cohort design), gender, geographical area, source of control (population and hospital), sample size, dietary assessment, family history and dietary energy intake for adjustments showed no significant impact on between-study heterogeneity (data not shown).

\section{Publication bias}

Publication bias was evaluated with both Funnel plots and Egger's tests. As shown in Fig. 3. The shapes of symmetrical funnel plot show little evidence of publication bias among the studies. Moreover, Egger's test showed no significant publication bias in this metaanalysis $(t=-0.06, P=0.957)$.

\section{Discussion}

In this meta-analysis, no significant association between dietary isoflavones intake and the risk of gastric cancer was detected. The subgroup analysis was also performed to further explore the relationship, which yield the similar result.

The incidence of gastric cancer has been shown to be associated with many dietary factors [13-19]. Previous studies found that higher intake of vegetables and fruits is a protective factor against gastric cancer $[3,20]$. Isoflavones, act as the role of estrogenic hormone, are rich in leguminous plants [21, 22]. Some studies showed an inverse association between dietary isoflavone intake and gastric cancer [6], however, some other studies demonstrated there is no effect of dietary isoflavone intake on gastric cancer [21, 22]. Previous studies had inconsistent findings regarding the association between isoflavones and gastric cancer risk. Therefore, it is necessary to perform a meta-analysis to further identify the associations.

Some epidemiological studies reported an inverse association between soy products and gastric risk [23, 24]. Sarah and Kweon revealed that consuming unfermented soy foods could decreased the risk of gastric cancer [25, 26]. A meta-analysis also reported that a high intake of unfermented soy foods is associated with a decreased gastric cancer risk [27]. Those findings are not agreement with our study which might be ascribed to the

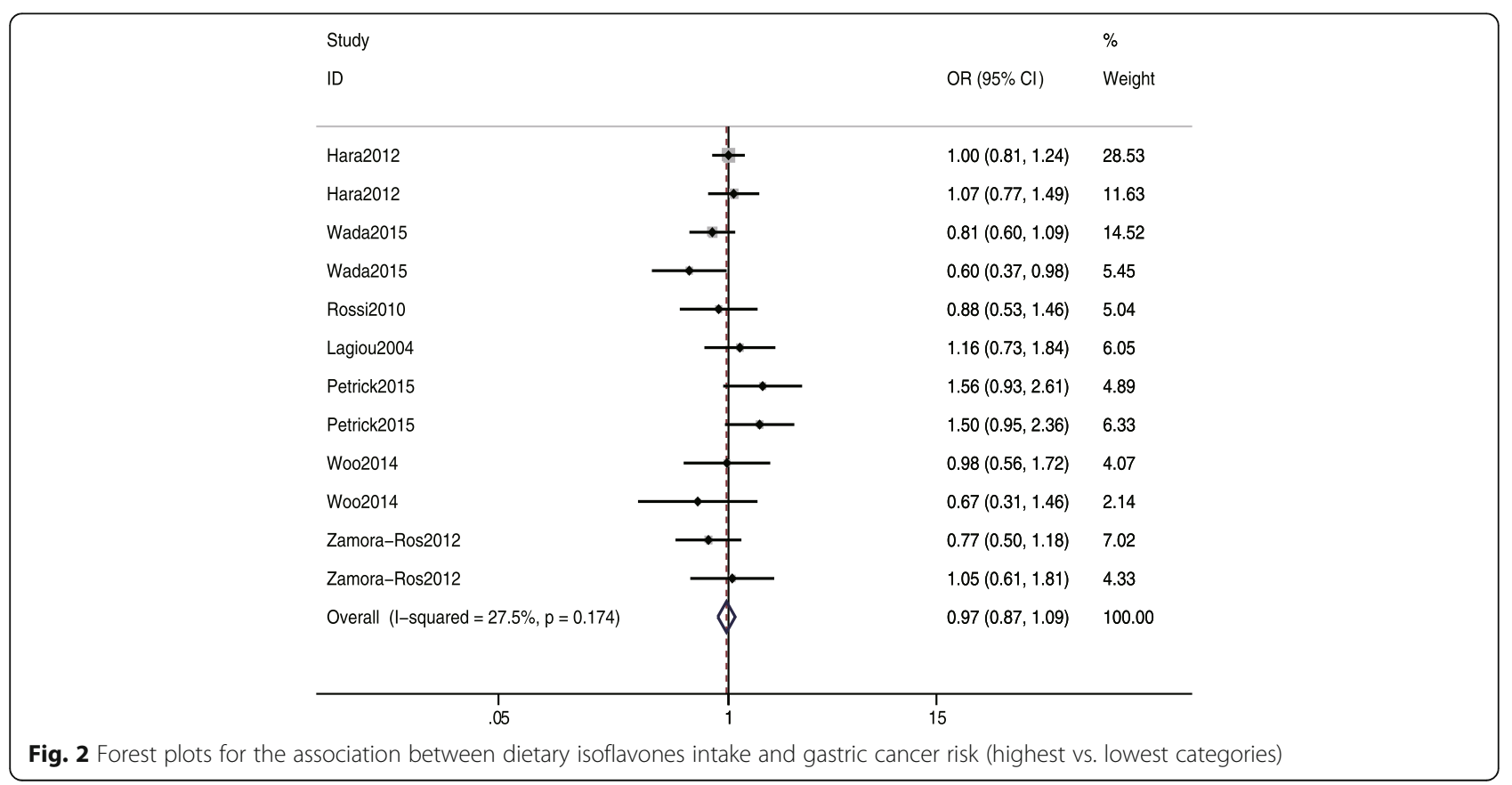


Table 2 Subgroup analysis of dietary isoflavones intake and gastric cancer risk

\begin{tabular}{|c|c|c|c|c|c|c|}
\hline \multirow[t]{2}{*}{ Subgroup } & \multirow{2}{*}{$\begin{array}{l}\text { Number of } \\
\text { participants }\end{array}$} & \multirow{2}{*}{$\begin{array}{l}\text { Number } \\
\text { of studies }\end{array}$} & \multirow[t]{2}{*}{ OR $(95 \% \mathrm{Cl})$} & \multirow{2}{*}{$\begin{array}{l}\text { Analysis } \\
\text { model }\end{array}$} & \multicolumn{2}{|c|}{ Heterogeneity test } \\
\hline & & & & & $\overline{P^{2}(\%)}$ & $P$ \\
\hline All studies & 596,553 & 12 & $0.97(0.87-1.09)$ & Fixed & 27.5 & 0.174 \\
\hline \multicolumn{7}{|l|}{ Study design } \\
\hline Cohort & 592,985 & 6 & $0.91(0.80-1.04)$ & Fixed & 15.2 & 0.316 \\
\hline Case-control & 3568 & 6 & $1.15(0.93-1.43)$ & Fixed & 15.4 & 0.315 \\
\hline \multicolumn{7}{|l|}{ Sex } \\
\hline Male & 196,443 & 4 & $0.91(0.78-1.06)$ & Fixed & 0 & 0.576 \\
\hline Female & 397,210 & 4 & $0.89(0.71-1.13)$ & Fixed & 34.1 & 0.208 \\
\hline Mixed & 2900 & 4 & $1.25(0.98-1.59)$ & Fixed & 8.6 & 0.350 \\
\hline \multicolumn{7}{|l|}{ Geographic area } \\
\hline Europe and America & 480,212 & 6 & $1.11(0.91-1.34)$ & Fixed & 29.2 & 0.316 \\
\hline Asia & 116,341 & 6 & $0.91(0.79-1.05)$ & Fixed & 12.5 & 0.335 \\
\hline \multicolumn{7}{|l|}{ Source of control } \\
\hline Population & 594,898 & 8 & $0.98(0.86-1.11)$ & Fixed & 48.5 & 0.059 \\
\hline Hospital & 1655 & 4 & $0.96(0.73-1.26)$ & Fixed & 0 & 0.663 \\
\hline \multicolumn{7}{|l|}{ Sample size } \\
\hline$\geq 750$ & 595,675 & 7 & $0.99(0.87-1.12)$ & Random & 51.9 & 0.052 \\
\hline$<750$ & 878 & 5 & $0.93(0.74-1.17)$ & Fixed & 0 & 0.640 \\
\hline \multicolumn{7}{|l|}{ Dietary assessment } \\
\hline$>100$ items & 595,566 & 10 & $0.97(0.86-1.09)$ & Fixed & 37.8 & 0.107 \\
\hline$\leq 100$ items & 987 & 2 & $1.02(0.73-1.44)$ & & 0 & 0.430 \\
\hline \multicolumn{7}{|l|}{ Adjustments } \\
\hline Family history, yes & 84,881 & 2 & $1.02(0.85-1.22)$ & Fixed & 0 & 0.737 \\
\hline No & 511,672 & 10 & $0.94(0.82-1.09)$ & & 38.6 & 0.101 \\
\hline Dietary energy intake, yes & 478,967 & 8 & $0.98(0.85-1.12)$ & Random & 0 & 0.868 \\
\hline No & 32,705 & 4 & $0.97(0.79-1.18)$ & & 75 & 0.007 \\
\hline
\end{tabular}

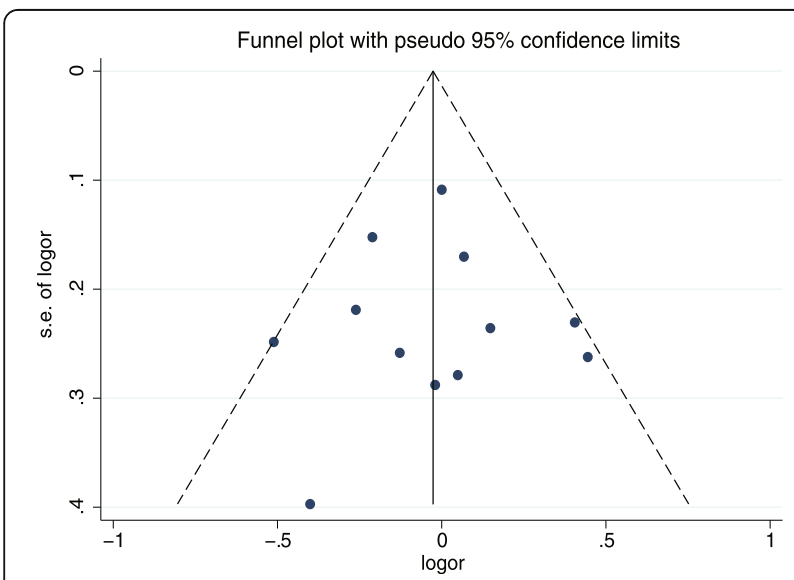

Fig. 3 Funnel plots of dietary isoflavones intake and the risk of gastric cancer possible confounding effects such as salt, vegetable, fruit, and other dietary factors. After adjusting for these dietary factors, Hara [6] found no association between soy food intake and gastric cancer risk, which is consistent with our study.

In the 12 studies we selected, an inverse association between dietary isoflavones and the risk of gastric cancer was only shown in a female cohort study. This may attribute to the insufficient possible confounders adjustment. Moreover, numerous animal studies and cytology experiments have widely demonstrated the anticancer property of isoflavones [28-30] for its antioxidant and antipromotional effects [31], however, our study did not detected any protective effect of isoflavones against gastric cancer. The inconsistency might be attributed to the following reasons: first, the exposure dose and concentrations of isoflavones used in vitro and in vivo studies is precise, which is difficult to obtain through habitual dietary intake by humans [32]. Second, the composition of the gut 
microflora, such as Helicobacter pylori, may influence isoflavones absorption and metabolism and production of specific intestinal microbial catabolites which may in turn mediate their biological activities. Third, potential small existing effect may be affect by uncontrolled variability that is difficult to quantify between human beings [33].

The meta-analysis study has several advantages. First, the potential confounding factors were adjusted in all individual studies (e.g. age, BMI, smoking status and alcohol drinking). In addition, the subgroup analysis was conducted to further explore the association and strengthened the results. Moreover, the pooled results might be unbiased because no publication bias was observed.

The potential limitations of our meta-analysis should be acknowledged. First, Helicobacter pylori infection which is a risk factor for gastric cancer is only reported in one case-control study. Second, the dose levels of dietary isoflavones are not well defined, so the effect of dietary isoflavones intake may be masked.

\section{Conclusions}

No significant association between dietary isoflavones intake and risk of gastric cancer was found in this metaanalysis, suggesting that dietary isoflavones intake is not associated with a decline in the risk of gastric cancer.

\section{Additional file}

Additional file 1: Data extraction from included studies. (XLSX 15 kb)

\section{Abbreviations}

BMl: Body mass index; Cls: Confidence intervals; F: Female; FFQ: Food frequency questionnaire; GCA: Gastric cardia adenocarcinoma; M: Male; NR: Not report; OG: Gastric adenocarcinoma; ORs: Odds ratios; RRs: Relative risks

\section{Acknowledgements \\ Thanks all the people for helping finishing the study, especially my supervisor and my senior sister apprentice. All authors have reviewed and approved the final manuscript.}

\section{Funding}

The present study was funded by the National Natural Science Foundation of China (Grant No. 8167120816)

\section{Authors' contributions}

The author's responsibilities were as follows - JY and YFS: data collection, statistics analysis, drafting and revision of the manuscript; YCB: data collection and data analysis; YWZ, DDD and HC: data extraction and data collection; QالL: study concept and design, revision of the manuscript. All authors read and approved the final manuscript.

\section{Ethics approval and consent to participate}

Not applicable.

\section{Competing interests}

The authors declare that they have no competing interests.

\section{Publisher's Note}

Springer Nature remains neutral with regard to jurisdictional claims in published maps and institutional affiliations.
Received: 19 October 2017 Accepted: 10 April 2018

Published online: 17 April 2018

\section{References}

1. Torre LA, Bray F, Siegel RL, Ferlay J, Lortet-Tieulent J, Jemal A. Global cancer statistics, 2012. CA Cancer J Clin. 2015;65(2):87-108.

2. Steevens J, Schouten LJ, Goldbohm RA, van den Brandt PA. Vegetables and fruits consumption and risk of esophageal and gastric cancer subtypes in the Netherlands cohort study. Int J Cancer. 2011;129(11):2681-93.

3. Shimazu T, Wakai K, Tamakoshi A, Tsuji I, Tanaka K, Matsuo K, Nagata C, Mizoue $T$, Inoue $M$, Tsugane $S$, et al. Association of vegetable and fruit intake with gastric cancer risk among Japanese: a pooled analysis of four cohort studies. Ann Oncol. 2014;25(6):1228-33.

4. Yu J, Bi X, Yu B, Chen D. Isoflavones: anti-inflammatory benefit and possible caveats. Nutrients. 2016;8(6):361.

5. Stang A. Critical evaluation of the Newcastle-Ottawa scale for the assessment of the quality of nonrandomized studies in meta-analyses. Eur J Epidemiol. 2010;25(9):603-5.

6. Hara A, Sasazuki S, Inoue M, Iwasaki M, Shimazu T, Sawada N, Yamaji T, Tsugane S, Japan Public Health Center-Based Prospective Study G. Isoflavone intake and risk of gastric cancer: a population-based prospective cohort study in Japan. Am J Clin Nutr. 2012;95(1):147-54.

7. Wada K, Tsuji M, Tamura T, Konishi K, Kawachi T, Hori A, Tanabashi S, Matsushita S, Tokimitsu N, Nagata C. Soy isoflavone intake and stomach cancer risk in Japan: from the Takayama study. Int J Cancer. 2015;137(4):885-92.

8. Zamora-Ros R, Agudo A, Lujan-Barroso L, Romieu I, Ferrari P, Knaze V, Bueno-de-Mesquita HB, Leenders M, Travis RC, Navarro C, et al. Dietary flavonoid and lignan intake and gastric adenocarcinoma risk in the European Prospective Investigation into Cancer and Nutrition (EPIC) study. Am J Clin Nutr. 2012;96(6):1398-408.

9. Lagiou P, Samoli E, Lagiou A, Peterson J, Tzonou A, Dwyer J, Trichopoulos D. Flavonoids, vitamin C and adenocarcinoma of the stomach. Cancer Causes Control. 2004;15(1):67-72.

10. Petrick JL, Steck SE, Bradshaw PT, Trivers KF, Abrahamson PE, Engel LS, He K, Chow WH, Mayne ST, Risch HA, et al. Dietary intake of flavonoids and oesophageal and gastric cancer: incidence and survival in the United States of America (USA). Br J Cancer. 2015;112(7):1291-300.

11. Rossi M, Rosato V, Bosetti C, Lagiou P, Parpinel M, Bertuccio P, Negri E, La Vecchia C. Flavonoids, proanthocyanidins, and the risk of stomach cancer. Cancer Causes Control. 2010;21(10):1597-604.

12. Woo HD, Lee J, Choi IJ, Kim CG, Lee JY, Kwon O, Kim J. Dietary flavonoids and gastric cancer risk in a Korean population. Nutrients. 2014;6(11):4961-73.

13. Rota M, Pelucchi C, Bertuccio P, Matsuo K, Zhang ZF, Ito H, Hu J, Johnson KC, Palli D, Ferraroni $M$, et al. Alcohol consumption and gastric cancer risk-a pooled analysis within the StoP project consortium. Int J Cancer. 2017;141:1950.

14. Hashemian M, Murphy G, Etemadi A, Dawsey SM, Liao LM, Abnet CC. Nut and peanut butter consumption and the risk of esophageal and gastric cancer subtypes. Am J Clin Nutr. 2017;106(3):858-64.

15. Hashemi SM, Mashhadi M, Moghaddam AA, Yousefi J, Mofrad AD, Sadeghi $M$, Allahyari $A$. The relationship between serum selenium and zinc with gastroesophageal cancers in the Southeast of Iran. Indian J Med Paediatr Oncol. 2017:38(2):169-72.

16. Lippi G, Mattiuzzi C, Cervellin G. Meat consumption and cancer risk: a critical review of published meta-analyses. Crit Rev Oncol Hematol. 2016;97:1-14.

17. Song P, Wu L, Guan W. Dietary nitrates, nitrites, and nitrosamines intake and the risk of gastric cancer: a meta-analysis. Nutrients. 2015;7(12):9872-95.

18. Wang $X Q$, Yan H, Terry PD, Wang JS, Cheng L, Wu WA, Hu SK. Interaction between dietary factors and helicobacter pylori infection in noncardia gastric cancer: a population-based case-control study in China. J Am Coll Nutr. 2012:31(5):375-84.

19. Kurosawa M, Kikuchi S, Xu J, Inaba Y. Highly salted food and mountain herbs elevate the risk for stomach cancer death in a rural area of Japan. J Gastroenterol Hepatol. 2006;21(11):1681-6.

20. Raei N, Behrouz B, Zahri S, Latifi-Navid S. Helicobacter pylori infection and dietary factors act synergistically to promote gastric cancer. Asian Pac J Cancer Prev. 2016;17(3):917-21

21. Kaufman PB, Duke JA, Brielmann H, Boik J, Hoyt JE. A comparative survey of leguminous plants as sources of the isoflavones, genistein and daidzein: implications for human nutrition and health. J Altern Complement Med. 1997;3(1):7-12. 
22. Rafii F. The role of colonic bacteria in the metabolism of the natural isoflavone daidzin to equol. Meta. 2015;5(1):56-73.

23. Ko KP, Park SK, Yang JJ, Ma SH, Gwack J, Shin A, Kim Y, Kang D, Chang SH, Shin HR, et al. Intake of soy products and other foods and gastric cancer risk: a prospective study. J Epidemiol. 2013;23(5):337-43.

24. Tong $X$, Li W, Qin LQ. Meta-analysis of the relationship between soybean product consumption and gastric cancer. Zhonghua Yu Fang Yi Xue Za Zhi. 2010;44(3):215-20.

25. Yang S, Park Y, Lee J, Choi IJ, Kim YW, Ryu KW, Sung J, Kim J. Effects of soy product intake and interleukin genetic polymorphisms on early gastric cancer risk in Korea: a case-control study. Cancer Res Treat. 2017;49(4):1044-56.

26. Kweon SS, Shu XO, Xiang Y, Cai H, Yang G, Ji BT, Li H, Gao YT, Zheng W, Epplein M. Intake of specific nonfermented soy foods may be inversely associated with risk of distal gastric cancer in a Chinese population. J Nutr. 2013;143(11):1736-42.

27. Kim J, Kang M, Lee JS, Inoue M, Sasazuki S, Tsugane S. Fermented and nonfermented soy food consumption and gastric cancer in Japanese and Korean populations: a meta-analysis of observational studies. Cancer Sci. 2011;102(1):231-44.

28. Ambrosio R, Ombra MN, Gridelli C, Picariello G, DI Stasio M, Volpe MG. Isoflavone extracts enhance the effect of epidermal growth factor receptor inhibitors in NSCLC cell lines. Anticancer Res. 2016:36(11):5827-33.

29. Messina M, Bennink M. Soyfoods, isoflavones and risk of colonic cancer: a review of the in vitro and in vivo data. Baillieres Clin Endocrinol Metab. 1998;12(4):707-28.

30. Yanagihara $\mathrm{K}$, Ito A, Toge T, Numoto M. Antiproliferative effects of isoflavones on human cancer cell lines established from the gastrointestinal tract. Cancer Res. 1993;53(23):5815-21.

31. Wei H, Bowen R, Cai Q, Barnes S, Wang Y. Antioxidant and antipromotional effects of the soybean isoflavone genistein. Proc Soc Exp Biol Med. 1995; 208(1):124-30

32. Zhou HB, Chen JM, Cai JT, Du Q, Wu CN. Anticancer activity of genistein on implanted tumor of human SG7901 cells in nude mice. World J Gastroenterol. 2008;14(4):627-31.

33. Tse G, Eslick GD. Soy and isoflavone consumption and risk of gastrointestinal cancer: a systematic review and meta-analysis. Eur J Nutr. 2016;55(1):63-73.

Ready to submit your research? Choose BMC and benefit from:

- fast, convenient online submission

- thorough peer review by experienced researchers in your field

- rapid publication on acceptance

- support for research data, including large and complex data types

- gold Open Access which fosters wider collaboration and increased citations

- maximum visibility for your research: over $100 \mathrm{M}$ website views per year

At BMC, research is always in progress.

Learn more biomedcentral.com/submissions 